\title{
ANALISIS KEPUASAN KONSUMEN RESTORAN CEPAT SAJI MENGGUNAKAN METODE PARTIAL LEAST SQUARE (Studi Kasus: Burger King Bali)
}

\author{
Made Sanjiwani $^{\S 1}$, Ketut Jayanegara ${ }^{2}$, I Putu Eka Nila Kencana ${ }^{3}$ \\ ${ }^{1}$ Jurusan Matematika, Fakultas MIPA - Universitas Udayana [Email: sanjisanjiwani@ gmail.com] \\ ${ }^{2}$ Jurusan Matematika, Fakultas MIPA - Universitas Udayana [Email: ketut_jayanegara@yahoo.com] \\ ${ }^{3}$ Jurusan Matematika, Fakultas MIPA - Universitas Udayana [Email: i.putu.enk@gmail.com] \\ ${ }^{\S}$ Corresponding Author
}

\begin{abstract}
The were two aims of this research. First is to get model of the relation between the latent variable quality of service and product quality to customer satisfaction. The second was to determine the influence of service quality on customer satisfaction and the influence of product quality on consumer satisfaction at Burger King Bali. This research implemented Partial Least Square method with 3 second order variables is the service quality, product quality, and customer satisfaction. In this research also used 5 first order variables to explain the variable service quality are tangibles, empathy, reliability, responsiveness, assurance and 6 first order variables to explain the variable quality product are performance, reliability, feature, durability, conformance, and design. Samples used in this research is 100. The results of this research indentify that the service quality and product quality affect customer satisfaction at Burger King.
\end{abstract}

Keywords: Customer Satisfaction, Partial Least Square (PLS), Products Quality, Quality of Service.

\section{PENDAHULUAN}

Analisis statistika multivariat merupakan salah satu teknik statistika yang mana dalam penerapannya sangat luas, baik dalam ilmuilmu sosial maupun sains. Oleh karena itu teknik analisis ini dapat diterapkan pada berbagai jenis penelitian seperti : survei dan eksperimen. Berdasarkan hubungan antar variabel, analisis multivariat dapat dibedakan menjadi analisis dependensi dan analisis interdependensi [1].

Analisis dependensi adalah teknik yang digunakan untuk menjelaskan hubungan atau pengaruh satu atau banyak variabel terhadap variabel lainnya [2]. Analisis interdependensi adalah teknik yang dilakukan untuk melakukan pengelompokan, baik terhadap variabel maupun objek. Dalam analisis interdependensi kedudukan setiap variabel sama, tidak ada variabel terikat atau variabel bebas. Biasanya analisis interdependensi ini digunakan untuk melihat saling keterkaitan hubungan antar semua variabel tanpa memperhatikan jenis variabel yang dilibatkan [2].

Structural Equation Model (SEM) merupakan teknik analisis multivariat yang merupakan gabungan antara analisis regresi yang diterapkan pada analisis antara variabel laten dengan analisis faktor yang diterapkan pada analisis antar indikator. Sedangkan berdasarkan hubungan antar variabelnya SEM termasuk dalam analisis interdependensi. Terdapat dua SEM yaitu SEM berbasis kovarian dan SEM berbasis varian [2]. SEM berbasis kovarian sering disebut sebagai hard modeling yang didasari oleh asumsi data berdistribusi normal multivariat dan jumlah sampel yang besar. Selain itu, indikator hanya dalam bentuk reflektif, dan model berdasarkan pada teori, sedangkan SEM berbasis varian sering disebut sebagai soft modeling yang tidak didasari oleh banyak asumsi seperti data tidak harus berdistribusi normal multivariat (indikator dengan skala kategori, ordinal, 
interval sampai ratio dapat digunakan pada model yang sama), jumlah sampel tidak harus besar [3].

Partial Least Square (PLS) merupakan metode alternatif dari SEM berbasis varian. Terdapat dua model pada PLS yakni inner model yaitu hubungan antara variabel laten dengan variabel laten yang lain dan outer model yaitu hubungan antara variabel laten dengan indikatornya [2]. Variabel laten (latent variable) merupakan variabel yang tidak terukur atau tidak teramati secara langsung. Salah satu contoh variabel laten yaitu kepuasan konsumen. Pada suatu usaha yang bergerak di bidang makanan contohnya restoran cepat saji, kepuasan konsumen merupakan suatu tolak ukur keberhasilan usaha tersebut.

Berdasarkan uraian di atas, penulis ingin mengetahui bagaimanakah bentuk model Partial Least Square (PLS) variabel-variabel laten kualitas layanan dan kualitas produk terhadap variabel laten kepuasan konsumen dan bagaimana pengaruh variabel-variabel laten kualitas layanan dan kualitas produk terhadap variabel laten kepuasan konsumen di Burger King Bali

\section{METODE PENELITIAN}

Penelitian ini menggunakan metode PLS dengan data yang digunakan dalam penelitian ini adalah data primer yang diperoleh secara langsung dari konsumen yang berbelanja di Burger King Bali dengan menggunakan kuisioner. Jumlah sampel penelitian yang akan digunakan adalah sebanyak 100 responden konsumen lokal yang berbelanja di Burger King. Penarikan sampel menggunakan metode sampling aksidental, yaitu konsumen Burger King yang ditemui peneliti dan cocok digunakan sebagai sampel.

Penelitian ini, menggunakan 3 variabel laten second order yaitu: 1) variabel laten kepuasan konsumen, 2) variabel laten kualitas layanan, dengan 5 first order yaitu tangibles, empathy, reliability, responsiveness, dan assurance, 3) Variabel laten kualitas produk dengan 6 variabel first order yaitu performance, reliability, feature, durability, conformance, dan design.

Adapun rancanagan model struktural yang digunakan dalam penelitian ini adalah sebagai berikut:

The design of structural models used in this study are as follows:

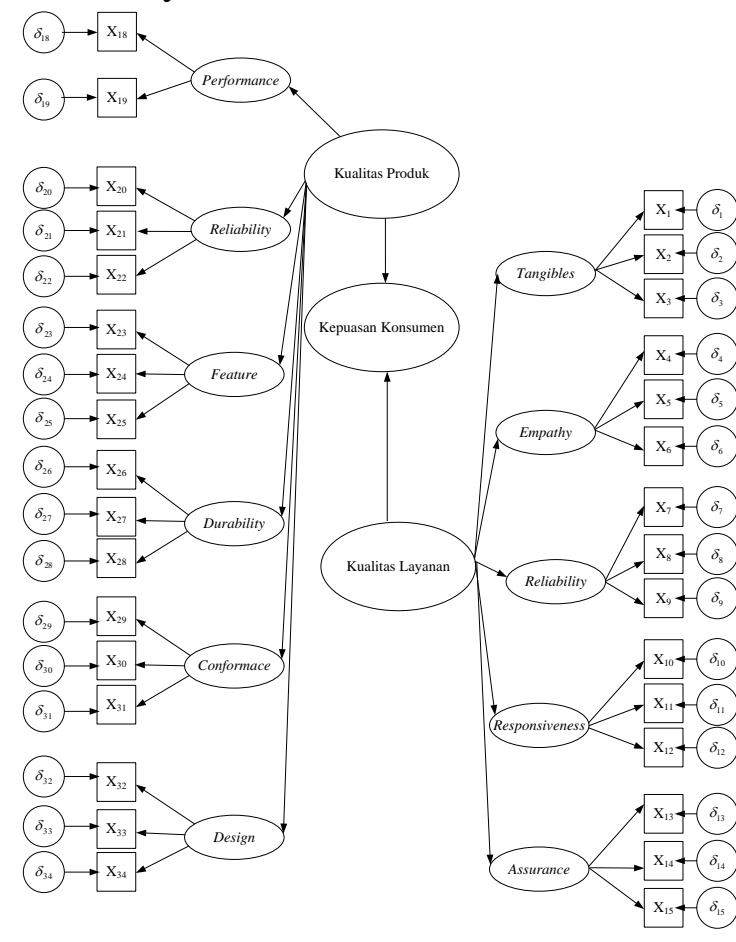

Gambar 1

Keterangan:

$\mathrm{X}_{1}$ : Kebersihan fasilitas fisik restoran

$\mathrm{X}_{2}$ : Kerapian penampilan karyawan

$\mathrm{X}_{3}$ : Kemutakhiran (kemodernan) sarana fisik yang dimiliki

$\mathrm{X}_{4}$ : Perhatian secara personal oleh karyawan Burger King

$\mathrm{X}_{5}$ : Mudah diakses

$\mathrm{X}_{6}$ : Memperhatikan kebutuhan konsumen dengan sungguh-sungguh

$\mathrm{X}_{7}$ : Burger King menyediakan jasa pelayanan dengan baikdari awal hingga akhir

$\mathrm{X}_{8}$ : penanganan atau pengadministrasian catatan/dokumen (misal, struk pembelian)

$\mathrm{X}_{9}$ : Pelayanan sesuai dengan yang dijanjikan

$\mathrm{X}_{10}$ : Kesediaan karyawan dalam memberika pelayanan yang cepat 
$\mathrm{X}_{11}$ : Kesediaan karyawan dalam membantu kesulitan konsumen dengan cepat

$\mathrm{X}_{12}$ : Keluangan waktu karyawan untuk menanggapi permintaan konsumen dengan cepat

$\mathrm{X}_{13}$ : Reputasi perusahaan yang terjamin

$\mathrm{X}_{14}$ : Kompetensi(kemampuan) karyawan dalam bidang pelayanan restoran yang diberikan

$\mathrm{X}_{15}$ : Keramahan karyawan dalam memberikan layanan

$\mathrm{X}_{18}$ : Jumlah pilihan produk

$\mathrm{X}_{19}$ : Produk penciri

$\mathrm{X}_{20}$ : Keakuratan produk

$\mathrm{X}_{21}$ : Jaminan aman

$\mathrm{X}_{22}$ : Kesesuaian produk nyata dengan gambar

$\mathrm{X}_{23}$ : Bahan-bahan penyusun produk

$\mathrm{X}_{24}$ : Pilihan menu tambahan

$\mathrm{X}_{25}$ : Fleksibelitas produk

$\mathrm{X}_{26}$ : Produk spesial yang lebih awet

$\mathrm{X}_{27}$ : Daya tahan produk

$\mathrm{X}_{28}$ : Pengemasan yang baik

$\mathrm{X}_{29}$ : Kecepatan penyajian

$\mathrm{X}_{30}$ : Kesesuaian standar

$\mathrm{X}_{31}$ : Kesesuaian aturan

$\mathrm{X}_{32}$ : Pengemasan yang rapi

$\mathrm{X}_{33}$ : Pengemasan yang bersih

$\mathrm{X}_{34}$ : Penataan produk

Langkah-langkah untuk analisis data dengan metode Partial Least Square (PLS), sebagai berikut:

i. Merancang model struktual (hubungan antara variabel laten).

ii. Merancang model pengukuran (hubungan antara variabel laten dengan indikator).

iii. Mengkonstruksi diagram jalur.

iv. Mengestimasi parameter

v. Evaluasi goodness fit model.

vi. Pengujian hipotesis

vii. Membuat kesimpulan.

\section{HASIL DAN PEMBAHASAN}

Sebagai tahap awal analisis dilakukan dengan melakukan pengujian kelayakan instrumen penelitian atau pengujian validitas dan reliabilitas, dalam penelitian ini dilakukan terhadap kuesioner yang telah disebarkan sebanyak 100 untuk konsumen lokal di Burger King. Suatu item dalam instrument dinyatakan valid, apabila nilai koefisien korelasi antara item pertanyaan dengan skor total sebesar $\geq$ 0.30 [4]. Selanjutnya, suatu instrument pengukuran yang digunakan dikatakan reliable (dapat dipercaya) jika nilai Cronbach Alpha $\geq$ 0.60 [4].

Dengan menggunakan bantuan software, kualitas layanan memiliki nilai corrected itemtotal correlation masing-masing 0.450, 0.404, $0.352,0.600,0.518,0.686,0.475,0.330$, $0.428,0.460,0.347,0.386,0.428,0.451,0.63$. Nilai tersebut menunjukkan bahwa $X_{1}, X_{2}, X_{3}$, $\mathrm{X}_{4}, \mathrm{X}_{5}, \mathrm{X}_{6}, \mathrm{X}_{7}, \mathrm{X}_{8}, \mathrm{X}_{9}, \mathrm{X}_{10}, \mathrm{X}_{11}, \mathrm{X}_{12}, \mathrm{X}_{13}, \mathrm{X}_{14}$, dan $X_{15}$ valid, karena sebuah item pernyataan dinyatakan valid dalam suatu pengukuran apabila memiliki nilai korelasi $\geq 0.3$. Sedangkan nilai cronbach alpha yaitu 0.826 menyatakan bahwa suatu instrument pengukuran yang digunakan untuk mengukur kualitas layanan dapat dipercaya karena nilai Cronbach Alpha $\geq 0.60$.

Selanjutnya, variabel kualitas produk yaitu $X_{18}, X_{19}, X_{20}, X_{21}, X_{22}, X_{23}, X_{24}, X_{25}, X_{26}, X_{29}$, $\mathrm{X}_{30}, \mathrm{X}_{31}, \mathrm{X}_{32}, \mathrm{X}_{33}$, dan $\mathrm{X}_{34}$ dinyatakan valid, namun $\mathrm{X}_{16}, \mathrm{X}_{17}, \mathrm{X}_{27}$, dan $\mathrm{X}_{28}$ dinyatakan tidak valid dalam pengukuran kualitas produk, karena nilai corrected item-total correlation dari $\mathrm{X}_{16}, \mathrm{X}_{17}, \mathrm{X}_{27}$, dan $\mathrm{X}_{28}$ kurang dari atau sama dengan 0.30 . Sedangkan nilai cronbach alpha yaitu 0.819 yang ditunjukkan pada tabel 4.3 menyatakan bahwa suatu instrument pengukuran yang digunakan dapat dipercaya karena nilai Cronbach Alpha $\geq 0.60$. Dari hasil yang diperoleh menunjukkan bahwa terdapat empat item yang memiliki nilai korelasi dibawah 0.3 yaitu item $\mathrm{X}_{16}, \mathrm{X}_{17}, \mathrm{X}_{27}$, dan $\mathrm{X}_{28}$ dengan nilai korelasi secara berturutturut sebesar $0.245,0.43,0.286$, dan 0.277 sehingga diputuskan untuk mengeluarkan $\mathrm{X}_{16}$ dan $X_{17}$ dari model penelitian. Sementara $X_{27}$ dan $\mathrm{X}_{28}$ dengan nilai korelasi secara berturutturut sebesar 0.286 dan 0.277 tidak dikeluarkan dari model dengan pertimbangan pada variabel durability terdiri dari tiga indikator yaitu $\mathrm{X}_{26}, \mathrm{X}_{27}$, dan $\mathrm{X}_{28}$ apabila variabel $X_{27}$ dan $X_{28}$ dihilangkan dari model 
maka variabel laten durability tidak dapat dijelaskan oleh satu indikator.

Hasil uji kelayakan instrumen dari 34 item pernyataan pada kuesioner penelitian menunjukkan bahwa terdapat 2 item pernyataan yang dikeluarkan dalam model yaitu item $\mathrm{X}_{16}$ dan $\mathrm{X}_{17}$ dari variabel kualitas produk.

Evaluasi pada outer model ini dilakukan dengan melihat nilai outer loading untuk indikator yang bersifat reflektif, sedangkan untuk indikator yang bersifat formatif dapat melihat nilai regression weight-nya. Pada penelitian ini, pengukuran yang akan digunakan adalah outer loading sebab indikator dari setiap variabel laten bersifat reflektif. Sedangkan evaluasi pada inner model/structural model. bertujuan untuk melihat bagaimana hubungan antara variabel laten dengan variabel laten lainnya (inner model/structural model). Model struktural pada penelitian ini dibentuk dengan melibatkan first order latent dan second order latent, sehingga dalam menganalisis inner model akan dilakukan dalam dua tahapan yaitu dengan melihat hubungan antara first order latent dengan second order latent, kemudian dilanjutkan dengan melihat hubungan antara first order yang satu dengan first order latent lainnya.

Adapun penduga-penduga untuk masingmasing jalur yang disajikan dalam Gambar 2 berikut ini :

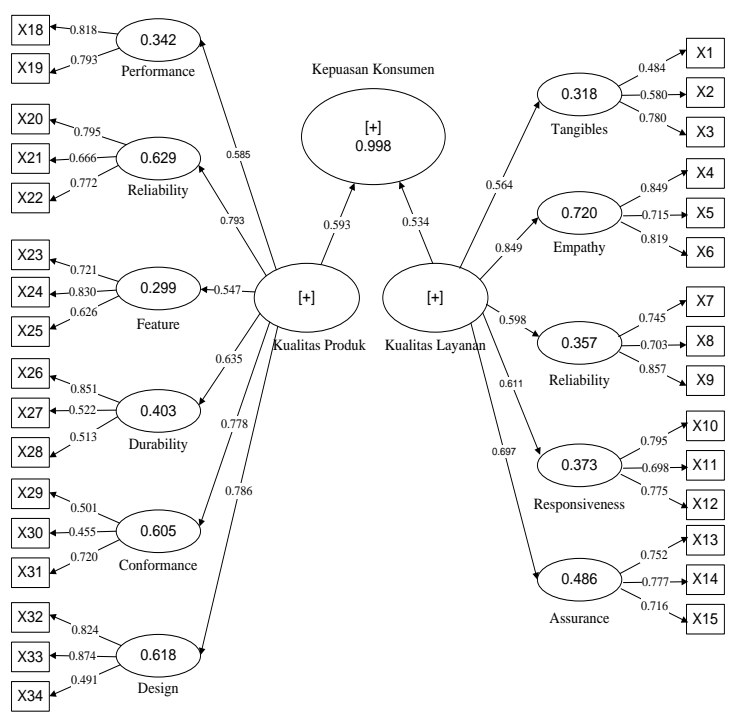

Gambar 2
Dari Gambar 2 akan dijelaskan mengenai variabel laten kualitas produk dan kualitas layanan yang merupakan variabel yang memengaruhi kepuasan konsumen.

\section{Kualitas Layanan}

Dari hasil penelitian Gambar 2 menunjukkan sebagai laten reflektif yang semua indikatornya berpengaruh signifikan dengan t-statistik $>1.987$, dalam penelitian ini memperlihatkan kualitas layanan direfleksikan atau ditunjukkan oleh tangibles, empathy, reliability, responsiveness, dan ansurance. Kualitas layanan secara signifikan merefleksikan ke lima variabel laten tersebut dengan empathy memiliki kemampuan reflektif yang lebih besar dibandingkan dengan tangibles, reliability, responsiveness, dan ansurance.

Pemeriksaan item-item refleksi dari tangibles di restoran cepat saji Burger King menunjukkan item sarana fisik (sarana makan, meja, tempat duduk, tempat cuci tangan, toilet) yang ditawarkan dan kerapian karyawan di Burger King sebagai dua item yang memiliki loading terkecil dibandingkan dengan 15 item lainnya. Hal tersebut mengkonfirmasi bahwa dalam hal kualitas layanan untuk memenuhi kepuasan konsumen sarana fisik yang ditawarkan dan kerapian karyawan sangat memengaruhi tercapainya kepuasan konsumen. Sehingga hal yang harus dijadikan prioritas untuk mencapai kepuasan konsumen di Burger King adalah dari segi sarana fisik restoran tersebut. Baik itu kebersihan atau kelengkapan sarana fisik restoran. Serta dukungan dari faktor individu karyawan itu sendiri yang terlihat dari kerapiannya.

Pada Gambar 2 menunjukkan nilai loading pada empathy, reliability, responsiveness, dan ansurance dari indikator pada masing-masing variabel laten tersebut memiliki nilai loading yang saling berdekatan yang artinya indikatorindikator tersebut telah dianggap baik dapat merefleksikan masing-masing variabel laten dalam mengukur kepuasan konsumen melalui kualitas layanan. Dari hasil penelitian juga diperoleh empathy merupakan refleksi dari 
kualitas layanan yang memiliki nilai koefisien jalur terbesar yaitu 0.849 yang artinya kualitas layanan didominasi oleh empathy dalam mencapai kepuasan konsumen.

Kualitas layanan berpengaruh signifikan terhadap kepuasan konsumen. Pada hubungan antara kualitas layanan sebagai laten eksogen dan kepuasan konsumen sebagai laten endogen, hasil penelitian ini secara empirik membuktikan adanya pengaruh positif dari kualitas layanan terhadap kepuasan konsumen.

Koefisien jalur pada Gambar 2 memperlihatkan adanya peningkatan kualitas layanan 1 satuan akan memengaruhi kepuasan konsumen sebesar 0.534 satuan.

\section{Kualitas Produk}

Dari hasil penelitian Gambar 2 menunjukkan kualitas produk direfleksikan oleh performance, reliability, feature, durability, conformance dan design. Kualitas produk secara signifikan merefleksikan ke enam variabel laten tersebut dengan reliability memiliki kemampuan reflektif yang lebih besar dibandingkan dengan performance, feature, durability, conformance dan design.

Dari hasil penelitian yang diperoleh pemeriksaan item-item refleksi dari durability di restoran cepat saji Burger King menunjukkan item produk yang dijual di Burger King hanya burger sapi dan burger ayam memiliki loading terkecil dibandingkan dengan 17 item lainnya. Hal tersebut mengkonfirmasi jumlah jenis produk yang disajikan harus lebih ditingkatkan atau diusahakan lebih banyak variasinya. Sehingga menambahkan jumlah jenis produk harus dijadikan prioritas dalam usaha mencapai kepuasan konsumen di Burger King

Pada Gambar 2 menunjukkan nilai loading pada performance, reliability, dan future dari indikator pada masing-masing variabel laten tersebut memiliki nilai loading yang saling berdekatan yang artinya indikator-indikator tersebut telah dianggap baik dapat merefleksikan masing-masing variabel laten dalam mengukur kepuasan konsumen melalui kualitas produk. Dari hasil penelitian juga diperoleh reliability merupakan refleksi dari kualitas produk yang memiliki nilai koefisien jalur terbesar yaitu 0.793 yang artinya kualitas produk didominasi oleh reliability dalam mencapai kepuasan konsumen.

Kualitas produk berpengaruh signifikan terhadap kepuasan konsumen. Pada hubungan antara kualitas produk sebagai laten eksogen dan kepuasan konsumen sebagai laten endogen, hasil penelitian ini secara empirik membuktikan adanya pengaruh positif dari kualitas produk terhadap kepuasan konsumen. Koefisien jalur pada Gambar 2 memperlihatkan adanya peningkatan kualitas produk 1 satuan akan memengaruhi kepuasan konsumen sebesar 0.593 satuan.

Dari hasil penelitian pada Gambar 2 dapat diketahui Goodness of Fit Model yang diukur menggunakan R-square variabel laten endogen yaitu :

$\mathrm{Q}^{2}=1-\left(1-\mathrm{R}_{1}^{2}\right)\left(1-\mathrm{R}_{2}^{2}\right) \ldots\left(1-\mathrm{R}_{\mathrm{p}}^{2}\right)$
$\mathrm{Q}^{2}=1-(1-0.318)(1-0.720)(1-0.357)$
$(1-0.373)(1-0.486)(1-0.342)(1-$
$0.629)(1-0.299)(1-0.403)(1-0.605)($
$1-0.618)(1-0.998)=0.9999981$ Dengan nilai Q square yaitu 0.9999981 model dalam penelitian sudah baik.

\section{KESIMPULAN}

Dari hasil yang telah dipaparkan sebelumnya, dapat ditarik kesimpulan bahwa:

Bentuk model partial least square yang diperoleh adalah sebagai berikut:

Dengan nilai $Q^{2}=0.9999981$ model dikatakan sudah baik.

Kualitas layanan berpengaruh signifikan terhadap kepuasan konsumen. Adanya peningkatan kualitas layanan 1 satuan akan memengaruhi kepuasan konsumen sebesar 0.534 satuan. Empathy merupakan refleksi dari kualitas layanan yang memiliki nilai koefisien jalur terbesar yaitu 0.849 yang artinya kualitas layanan didominasi oleh 
empathy dalam mencapai kepuasan konsumen di Burger King.

Kualitas produk berpengaruh signifikan terhadap kepuasan konsumen. Adanya peningkatan kualitas produk 1 satuan akan memengaruhi kepuasan konsumen sebesar 0.593 satuan. Reliability merupakan refleksi dari kualitas produk yang memiliki nilai koefisien jalur terbesar yaitu 0.793 yang artinya kualitas produk didominasi oleh reliability dalam mencapai kepuasan konsumen.

\section{DAFTAR PUSTAKA}

[1] Usman, H., \& Sobari, N. (2013). Aplikasi Teknik Multivariate Untuk Riset Pemasaran. Jakarta: PT. RajaGrafindo Persada.

[2] Ghozali, I., 2011. Structural Equation Modeling Metode Alternatif Dengan Partial Least Square. 3rd ed. Semarang: Badan Penerbit Undip.

[3] Cronin, J. J. \& Taylor, S. A., 1992. Measuring Service Quality : A Reexaminator and Extension. Journal of Marketing. Volume 56.

[4] Nunnally, J. C., 1975. Psychometric Theory. 25 Years Ago and Now. American Educational Researcher Association, IV(14), pp. 7-21. 